\title{
Copyright and the Perfect Curve
}

Julie E. Cohen

Georgetown University Law Center, jec@law.georgetown.edu

This paper can be downloaded free of charge from:

https://scholarship.law.georgetown.edu/facpub/59

53 Vand. L. Rev. 1799-1819 (2000)

This open-access article is brought to you by the Georgetown Law Library. Posted with permission of the author. Follow this and additional works at: https://scholarship.law.georgetown.edu/facpub

Part of the Intellectual Property Law Commons, and the Law and Economics Commons 


\title{
GEORGETOWN LAW Faculty Publications
}

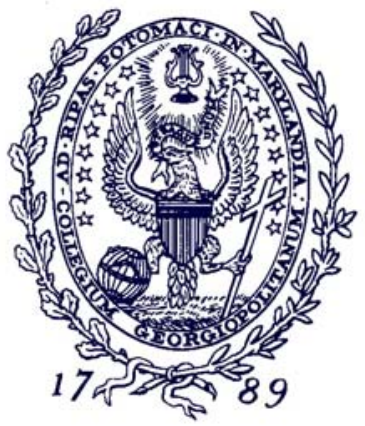 \\ January 2010

\section{Copyright and the Perfect Curve}

53 Vand. L. Rev. 1799-1819 (2000)

Julie E. Cohen

Professor of Law

Georgetown University Law Center

jec@law.georgetown.edu

This paper can be downloaded without charge from:

Scholarly Commons: http://scholarship.law.georgetown.edu/facpub/59/

SSRN: http://ssrn.com/abstract $=240590$

Posted with permission of the author 


\title{
Copyright and the Perfect Curve
}

\author{
Julie E. Cohen*
}

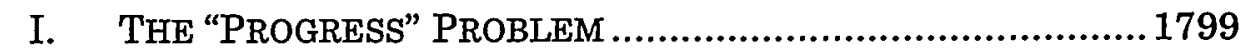

II. THE CONTRACTUAL PRICE DISCRIMINATION MODEL .......... 1801

III. COPYRIGHT AND THE QUALITY OF "PROGRESS" .................. 1808

IV. MODELING UNPREDICTABILITY .....................................1814

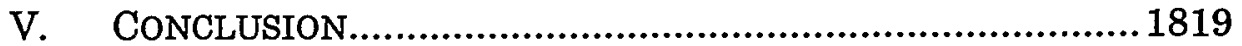

\section{THE "PROGRESS" PROBLEM}

Everyone agrees that the purpose of the copyright system is to promote progress. ${ }^{1}$ At the same time, though, skepticism about the law's ability to define the substance of progress runs deep within copyright case law and theory. Legal decisionmakers and scholars have quite properly doubted their own ability to evaluate artistic or literary merit, and have worried that efforts to do so would result in an inappropriately elitist and conservative standard. ${ }^{2}$ In addition, there is room for substantial debate about

* Associate Professor, Georgetown University Law Center. A.B. 1986, Harvard-Radcliffe; J.D. 1991, Harvard. Email: jec@law.georgetewn.edu. I thank the participants in Taking Stock: The Law and Economics of Intellectual Property Rights for their helpful comments, and especially thank J.H. Reichman for organizing the conference and inviting me to participate. $(2000$, Julie E. Cehen. Permission is hereby granted for copies of this essay to be made and distributed for educational use, provided that: (i) copies are distributed at or below cost; (ii) the author and the Vanderbilt Law Review are identified; and (iii) proper notice of copyright is affixed to each copy.

1. The Censtitution says so, after all. See U.S. CoNST. art. I, § 8, cl. 8 (authorizing Cengress te grant patents and copyrights "[t]o promote the Progress of Science and useful Arts").

2. For the most famous statement of this principle, see Bleistein v. Donaldson Lithographing Co., 188 U.S. 239, 251-52 (1902); see also Amy B. Cohen, Copyright Law and the Myth of Objectivity: The Idea-Expression Dichotomy and the Inevitability of Artistic Value Judgments, 66 IND. L.J. 175, 177, 184-95, 230-32 (1990) (summarizing the case for objectivity and arguing 1799 
whether the metaphor of forward motion leaves out other important measures of what "progress" is or might be. ${ }^{3}$

This agnosticism about prospects for value-neutrality has led copyright law and scholarship to eschew debates about the substance of progress in favor of debates about rule structures for enabling progress. Steeped in jurisprudential and scientific traditions that prize process and method, both in themselves and as proxies for value-neutral decisionmaking, we have decided that even if we cannot say what progress is, we can say something about the system of rules and entitlements that is most likely to promote it. This strategy, though, assumes that the substance of progress is independent of the legal structure designed to produce it. If it is not-if entitlement structures play a role in determining the kinds of new works that will be produced-then we cannot escape making decisions about substance, and it is folly to pretend otherwise.

This Essay argues that the assumption that "progress" is qualitatively independent of the underlying entitlement structure is wrong. In particular, I shall argue that a shift to a copyright rule structure based on highly granular, contractually enforced "price discrimination" would work a fundamental shift, as well, in the nature of the progress produced. The critique of the contractual price discrimination model, moreover, exposes deep defects in the use of neoclassical "law and economics" methodology to solve problems relating to the incentive structure of copyright law. What is needed, instead, is an economic model of copyright that acknowledges the central role of unpredictability in the creative process.

Part II introduces the contractual price discrimination model and critically examines the premises on which it is based. Part III considers the larger institutional and distributional implications of a shift to contractual price discrimination: It argues that the current system of imperfect controls produces important public benefits-important substantive components of "progress"-that the contractual price discrimination model does not accurately value

tbat decisions about copyrightability necessarily rest on value judgments); Monroe E. Price \& Malla Pollack, The Author in Copyright: Notes for the Literary Critic, 10 CARDOzo ARTS \& ENT. L.J. 703, 711-12 (1992) (considering the strengtbs and weaknesses of the objective approach to determining authorship); Alfred C. Yen, Copyright Opinions and Aesthetic Theory, 71 S. CAL. L. REV. 247 (1998) (showing that judges in copyright cases do in fact make judgments about artistic merit, and arguing that tbese judgments and the standards tbat inform them should be expressly acknowledged).

3. See generally Margaret Chon, Postmodern "Progress": Reconsidering the Copyright and Patent Power, 43 DEPAUL L. REV. 97 (1993) (comparing modern and postmodern ideas of progress). 
and would not itself produce to the same extent. Part IV concludes that the need to preserve these benefits, which stem from the inherent complexity and unpredictability of the creative process, requires both a very different structure for copyright law and a very different approach to the task of constructing economic models.

\section{The Contractual PRICE DiscRIMINation MODEL}

Copyright law conceives and promotes progress in two distinct but related ways: First, it seeks to increase both the quantity and quality of creative output. Second, it seeks to broaden public access to creative works. ${ }^{4}$ Advocates of the contractual price discrimination model argue that it is superior to the traditional copyright framework on both measures. This Part examines these arguments, and identifies important areas of uncertainty in the model's empirical and predictive claims.

The two "progress" goals exist in substantial tension with one another. The incentives that copyright law supplies to authors operate by restricting public access to and use of creative works. More specifically, the access restrictions enable copyright owners to charge prices above the marginal cost of producing additional copies of their works. The result is that there are consumers who want to purchase copies of the work, but are only willing (or able) to do so at a price lower than the monopoly price but higher than the work's marginal cost. Scholars have termed this effect-represented by Area 3 in Figure A, below-the "deadweight loss" created by copyright law. 5 To the extent that the widespread public availability of

4. The access criterion follows from the constitutional mandate te promote progress, both because "progress" is of little value unless its fruits are made available to the public, and because knowledge is cumulative, so that the public availability of creative works promotes furtber progress. See, e.g., Niva Elkin-Koren, Copyright Policy and the Limits of Freedom of Contract, 12 BERKELEY TECH. L.J. 93, 98-101 (1997); Robert A. Kreiss, Accessibility and Commercialization in Copyright Theory, 43 UCLA L. REv. 1, 10-14 (1995); William M. Landes \& Richard A. Posner, An Economic Analysis of Copyright Law, 18 J. LEGAL STUD. 325, 326-27 (1989); Mark A. Lemley, The Economics of Improvement in Intellectual Property Law, 75 TEx. L. REv. 989, 993-99 (1997); Jessica Litman, The Public Domain, 39 EMORY L.J. 965 (1990). But see Glynn S. Lunney, Jr., Reexamining Copyright's Incentives-Access Paradigm, 49 VAND. L. REV. 483, 487-88, 589-99 (1996) (arguing that in evaluating the success of a copyright regime, society also should consider the opportunity cost it creates, measured in terms of other, non-creative activities that might produce greater social welfare).

5. See, e.g., Elkin-Koren, supra note 4, at 99-100; William W. Fisher IIl, Property and Contract on the Internet, 73 CHI.-KENT L. REV. 1203, 1235-36 (1998); see generally Landes \& Posner, supra note 4 (offering the original version of this analysis). For ease of reference, in both Figure $A$ and Figure $B$, infra, I have used the same system of notation employed by Fisher in his recent treatment of the contractual price discrimination model. 
creative works promotes shared aspects of the general welfare, this deadweight loss represents both a failure to satisfy individual preferences and public benefit foregone.

Figure A: Economic Effects of First Sale Under Copyright

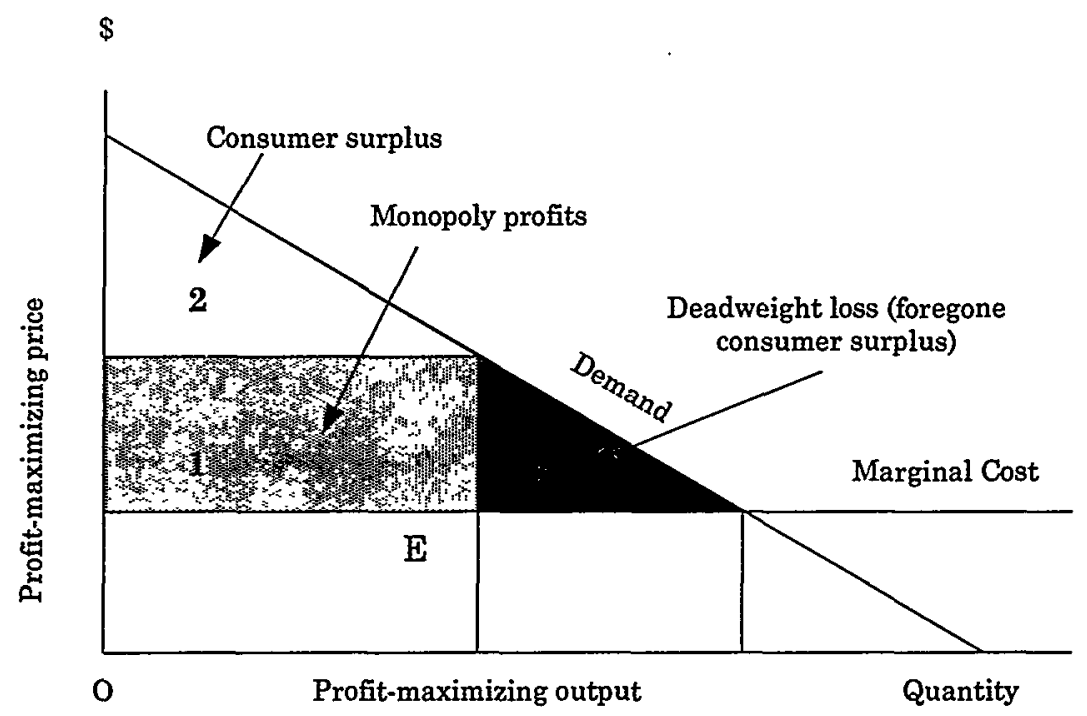

To ameliorate the incentives/access tradeoff, a number of economically oriented thinkers have advocated the use of contractually enforced "price discrimination"-charging different rates to different consumers, and prohibiting transfers that would allow consumers to engage in arbitrage. ${ }^{6}$ They envision a version of price discrimination under which the different prices will reflect access of varying quantity and/or quality. ${ }^{7}$ (I shall refer to this proposal as

6. For a concise explanation of price discrimination and its requirements, see Michael J. Meurer, Price Discrimination, Personal Use, and Piracy: Copyright Protection of Digital Works, 45 BUFF. L. REv. 845, 869-76 (1997).

7. See, e.g., Tom W. Bell, Fair Use vs. Fared Use: The Impact of Automated Rights Management on Copyright's Fair Use Doctrine, 76 N.C. L. REv. 557, 589 n.142 (1998); Fisher, supra note 5 at 1234-52; David Friedman, In Defense of Private Orderings: Comments on Julie Cohen's "Copyright and the Jurisprudence of Self-Help", 13 BERKELEY TECH. L.J. 1151, 1168-71 (1998); Maureen A. O'Rourke, Copyright Preemption After the ProCD Case: A Market-Based Approach, 12 BERKELEY TECH. L.J. 53, 62, 70-71 (1997); see also Yannis Bakos, et al., Shared Information Goods, 42 J.L. \& ECON. 117, 119-48 (1999) (assuming that this sort of price discrimination is desirable and exploring whether small-group sharing of information goods promotes or frustrates efficient price discrimination); Harold S. Demsetz, The Private Production of Public Goods, 13 J.L. \& EcON. 293, 295-306 (1970) (advocating price discrimination as a tool for enabling the private production of information goods). Fisher advances a modified price dis- 
"contractual price discrimination.") The proposal mirrors emerging market practices. Increasingly, information goods are "versioned" for buyers with different needs and resources. 8 Thus, evaluating the contractual price discrimination model's progress claims is important for practical as well as theoretical reasons.

The argument that contractual price discrimination will further copyright's dissemination goal is straightforward: Allowing monopolists to employ contractual price discrimination will promote consumer welfare, and ensure broader public distribution of creative works, by guaranteeing lower prices. ${ }^{9}$ The virtue of contractual price discrimination is that it replaces a single price with a range of prices. This enables lower-income consumers to purchase accessalbeit of lower quality-that they could not otherwise afford.

As to the effects of contractual price discrimination on creative progress, conventional economic wisdom holds that replacing a single price with a range of prices also will allow the copyright owner to appropriate a greater percentage of the consumer surplus attached to a particular work. This, in turn, will strengthen existing incentives for creation. ${ }^{10}$ For example, the copyright owner might charge higher rates for access to users who want to improve on (or compete with) the work in some way. The incentive effects for follow-on improvers are not forgotten, however. The conventional economic wisdom holds that rational copyright owners will license improvements (and also access) at prevailing market rates, and that market competition among copyright owners will keep rates reasonable. ${ }^{11}$

crimination model that incorporates some compulsory terms designed to serve the public interest. His proposal is considered more fully in Part IV, infra.

8. See CARL SHaPiro \& Hal R. VARIAN, INFORMATION RULES: A STRATEgic GUIDE to tHe NETWORK ECONCMY 53-81 (1999).

9. See Bell, supra note 7, at 561; Fisher, supra note 5, at 1237-40; Friedman, supra note 7, at 1169-70; O'Rourke, supra note 7, at 62,70-71.

10.See, e.g., Fisher, supra note 5, at 1237-39; Friedman, supra note 7, at 1169; Trotter Hardy, Property (and Copyright) in Cyberspace, 1996 U. CHI. LEGAL F. 217, 254-58; see also Meurer, supra note 6, at 877-80 (explaining how price discrimination can raise profits for copyright owners).

11.See, e.g., Bell, supra note 7, at 587-90, 601-08; Robert P. Merges, The End of Friction? Property Rights and Contract in the "Newtonian" World of On-Line Commerce, 12 BERKELEY TECH. L.J. 115, 120-28 (1997) [hereinafter Merges, End of Friction]; O'Rourke, supra note 7, at 80-87; see also Robert P. Merges, Contracting into Liability Rules: Intellectual Property Rights and Collective Rights Organizations, 84 CAL. L. REV. 1293, 1328 (1996) [hereinafter Merges, Liability Rules] (arguing that the licenses developed hy voluntarily constituted collective rights organizations will he "closely akin" to compulsory licenses); see generally Lemley, supra note 4, at 1044-47 (delineating the argument that the market will promote creative progress by allocating improvement rights to those who value them most highly). 
[Vol. 53:6:1799

The result of contractual price discrimination, according to its advocates, will be a system that is better for everyone. As Figure B illustrates, under contractual price discrimination there will be far less deadweight loss. At the other end of the demand curve, the gap between price and consumer surplus will shrink. The affected individuals, though, will still be getting the work at prices they are willing to pay. And everyone will benefit-or so the account goesfrom the increased creative output that the ability to charge higher prices will guarantee.

Figure B: Economic Effects of Contractual Price Discrimination

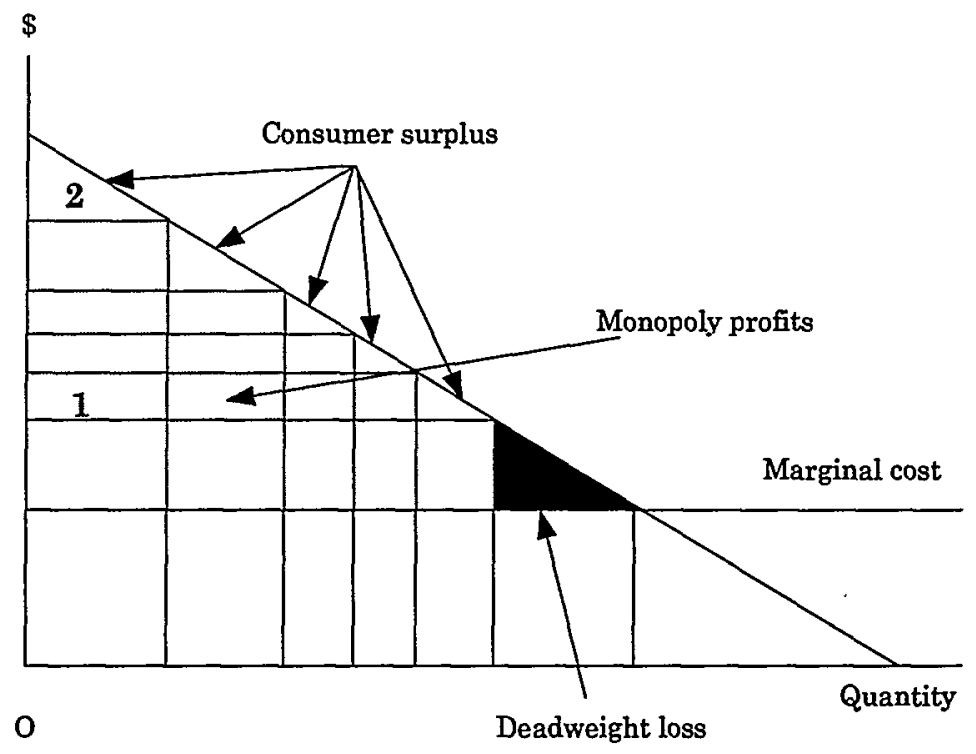

For the contractual price discrimination model to work, though, copyright owners need to be able to change some of the ground rules set by copyright law. Effective price discrimination requires restrictions on transfer of the work to other users; price discrimination will not work if high-value arbitrageurs can obtain low-cost access from redistributors. ${ }^{12}$ Copyright law, in contrast, allows the owner to control only the first sale of the work, and places no restrictions on the rental or lending of most works. ${ }^{13}$ Thus, we would need to allow copyright owners to opt out of the first sale doctrine, and to set and enforce restrictions on transfer of

12.See Meurer, supra note 6, at 874-76.

13.See 17 U.S.C. § 109(a) (1996); see also id. § 109(b) (restricting the rental or lending of computer software and sound recordings). 
works to other users. In addition, since reuse privileges are a factor in determining the quality of access, we would need to allow copyright owners the freedom to contract around copyright limitations such as the idea-expression distinction or the fair use doctrine if this would help lower prices for some users. ${ }^{14}$

In short, a cornerstone of the contractual price discrimination model is that the statutory scheme of copyright must be considered simply a system of default rules that may be changed by contract. A growing body of copyright scholarship supports these modifications. ${ }^{15}$ Proponents range from the major copyright industries, which want more protection than current copyright law alone can provide, to libertarian thinkers, who believe that contract is more flexible and more responsible to individual preferences than a standardized, legislative copyright regime. ${ }^{16}$

Whether we should treat traditional copyright rules as mere defaults, though, depends on whether the conventional economic

14.See Bell, supra note 7, at 561, 588-89; O'Rourke, supra note 7, at $62,70-71$; see also Fisher, supra note 5, at 1241-52 (endorsing this view but arguing that the law should preserve certain exceptions); Merges, End of Friction, supra note 11, at 134-35 (same); Maureen A. O'Rourke, Fencing Cyberspace: Drawing Borders in a Virtual World, 82 MINN. L. Rev. 609, 69596 (1998) [hereinafter O'Rourke, Fencing Cyberspace] (approving Merges' approach for Internet hyperlinks). Important copyright limitations include 17 U.S.C. $\$ \S 102(b)$ (1996) (excluding from copyright protection ideas, methods of operation, and the like), 107 (fair use doctrine), 108 (copying privileges for libraries), 109(a) (first sale doctrine), 110 (public performance and display exemptions for nonprofit activities and organizations). See also Feist Publications, Inc. v. Rural Tel. Serv. Co., Inc., 499 U.S. 340, 349-50 (1991) (holding that the denial of copyright protection for facts is constitutionally compelled).

15.See Bell, supra note 7, at 617; Tom W. Bell, Exit from Copyright: Market Success us. Statutory Failure in the Protection of Expressive Works (working paper Apr. 30, 2000) (on file with author); Friedman, supra note 7, at 1155; Hardy, supra note 10, at 224; Merges, Liability Rules, supra note 11, at 1347; O'Rourke, supra note 7, at 62, 70-71; see also Merges, Liability Rules, supra note 11, at 1328 (predicting that under a regime of more complete entitlements, copyright owners will develop efficient collective institutions for valuing, managing, and licensing their rights); see generally Ian Ayres \& Robert Gertner, Filling Gaps in Incomplete Contracts: An Economic Theory of Default Rules, 99 YALE L.J. 87, 87-91 (1989) (summarizing hiterature and discussing economic rationales for allowing parties to treat initial rules as defaults that may be varied).

16. Compare Robert W. Gomulkiewicz, The License is the Product: Comments on the Promise of Article 2B for Software and Information Licensing, 13 BERKELEY TECH. L.J. 891, 903 (1998) (arguing that the software and information industries need the fiexibility to configure licenses according to emerging business models), and Raymond T. Nimmer, Breaking Barriers: The Relation Between Contract and Intellectual Property Law, 13 BERkELEY TECH. L.J. 827, 878 (1998) (contending that intellectual property law generally presumes freedom of contract for intellectual property owners), with PAUL GOLDSTEIN, COPYRIGHT'S HIGHWAY: THE LAW AND LORE OF COPYRIGHT FROM GUTENBERG TO THE CELESTIAL JUKEBOX 216-17 (1994) (advocating the extension of hicensing because it will increase incentives for authors and make information markets more responsive to consumer preferences), and Bell, supra note 7, at 607.08 (asserting that legislatively decreed limitations on copyright scope "epitomize the kind of take-it-or-leave-it offer that foes of adhesion contracts so dislike"). 
interpretation of the demand curve is right. To summarize, that interpretation assumes that areas 2 and 3 under the demand curve in Figure A represent wasted opportunities to make copyright law more efficient, both distributively and productively. If so, it follows that the highest and best function of a hybrid copyright-contract regime should be to allow copyright owners to capture as much of the area under the demand curve as possible, thus (as in Figure B) making the correspondence between demand and distribution curves more perfect. There are, however, other possible readings of Figure A. It is important to understand what they are, in order to understand the choice that contractual price discrimination poses.

Turning first to distributional considerations, Area 3 in Figure A represents an absolute distributional shortfall only if we ignore the social institutions enabled by copyright law that traditionally have provided lower-income consumers with alternative means of access to works that they cannot afford to purchase outright. ${ }^{17}$ As Wendy Gordon reminds us, second-hand markets and public libraries also are methods of price discrimination that allow lowercost but less convenient access to copyrighted materials. ${ }^{18}$ Moreover, a rule allowing monopolists to price discriminate is not the only sort of rule that will reduce prices; competition against the traditional copyright backdrop of limited entitlements might produce the same result. ${ }^{19}$

The conventional reading of the demand and distribution curves under traditional copyright pricing reflects neither the utility realized by lower-income individuals who gain access through these alternative institutions nor the resulting increase in overall social welfare. Figures A and B measure only the copyright owner's ability to make a first sale to a particular consumer under different pricing (and legal) regimes. While it is clear that contractual price discrimination would make copyright owners better off, the welfare implications for lower-income individuals and for society generally are more debatable. ${ }^{20}$ Because Figures $A$ and $B$ offer no way of

17.See, e.g., 17 U.S.C. $\$ \S 108$ (1996) (establishing copying privileges for libraries), 109 (limiting the copyright owner's exclusive riglit to control distribution of the work to the first sale of copies for most works).

18.See Wendy J. Gordon, Intellectual Property as Price Discrimination: Implications for Copyright, 73 CHI.-KENT L. REV. 1367, 1372-75, 1388 (1998); cf. GoLDSTEIN, supra note 16, at 8 (illustrating the sorts of price discrimination currently practiced by copyright owners).

19.See Gordon, supra note 18, at 1388-89.

20.See Julie E. Cohen, Lochner in Cyberspace: The New Economic Orthodoxy of "Rights Management", 97 MICH. L. REV. 462, 498-99, 542-51 (1998) (discussing difference between private and social welfare, both generally and in the particular context of information markets). 
evaluating these implications, they are insufficient basis for concluding that contractual price discrimination represents an overall improvement.

As to the incentives argument offered by advocates of contractual price discrimination, it is important to recall, first, that Area 2 in Figure A represents not only lost incentives to copyright owners, but also the utility realized by more affluent users. Because we are using a model derived from commodity markets, we are conditioned to think of consumer surplus as unproductive. Whether or not that makes sense for ordinary consumer goods, it makes much less sense as applied to the production and consumption of information products, which have strong public good characteristics and may generate significant positive externalities. ${ }^{21}$ At least some of the heightened utility realized by affluent or high-value users will come from transformative reuses that create additional social welfare benefits-again, benefits that Figure A does not capture. Similarly, lower-income individuals who gain access to works through libraries and second-hand markets also may become creators. Figure A reflects neither the increased utility realized by those individuals nor the benefits realized by society generally. Finally, uncaptured consumer surplus also may induce its beneficiaries to purchase more copyrighted works than they might if forced to pay higher prices for each work, which in turn may result in the creation of new works that are informed by a broader, richer crosssection of our cultural capital.

In short, the distribution patterns generated by the traditional copyright framework are not necessarily less efficient than the new patterns that contractual price discrimination would cre-

21.A public good is a good tbat can be consumed without depletion (non-rivalrous consumption) and that can be withheld from nonpaying beneficiaries only at prohibitive cost (nonexcludability). See ROBERT COOTER \& THOMAS ULEN, LAW AND ECONOMICS 40-41 (2d ed. 1997). A positive externality is a benefit or gain that is not appropriated by the party or parties whose activities generated it. Seeid. at 38-40, 139-46 (defining externalities as costs or benefits arising from a market exchange that spill over onto third parties); ANDREAS A. PAPANDREOU, EXTERNALITY AND INSTITUTIONS 13-68 (1994) (analyzing and synthesizing leading approaches to defining and identifying externalities). Such benefits may accrue either to other private parties or to society generally. See Benjamin J. Bates, Information as an Economic Good: Sources of Individual and Soeial Value, in THE POLITICAL ECONOMY OF INFORMATION 76, 82-85 (Vincent Mosco \& Janet Wasko eds., 1988). On tbe positive social externalities generated by information goods, see C. Edwin Baker, Giving the Audience What It Wants, 58 OHIO ST. L.J. 311, 350-66 (1997); Cohen, supra note 20, at 542-51; Ezra J. Mishan, The Effects of Externalities on Individual Choice, 1 INT'L. REV. L. \& ECON. 97, 104-05 (1981); cf. William W. Fisher III, Reconstructing the Fair Use Doctrine, 101 HARV. L. REv. 1661, 1769-74 (1988) (identifying education, public debate, cultural diversity, and public access te information as among the social benefits produced by copyrighted works). 
ate. To a substantial degree, efficiency (or inefficiency) is in the eye of the beholder. ${ }^{22}$ Certainly, the patterns of distribution and access produced by a contractual price discrimination regime would be different than those produced currently. The relevant question, then, is whether the mix of "progress" produced under the two regimes would be different, and if so how.

Advocates of the contractual price discrimination model argue that from an institutional perspective, more complete markets in contractual restrictions might, and probably will, work more effectively than imperfect copyright monopolies to advance the dual goals of copyright. In part, as I have argued elsewhere, this is a normative claim about the meaning and importance of property rights. ${ }^{23}$ In part, though, it is a claim about the quantitative superiority of one rule system over another (along both productive and distributive dimensions)-and so, implicitly, about the valueneutrality of institutional choices with respect to qualitative measures of progress. Part III considers the qualitative dimension of this latter claim.

\section{II. COPYRIGHT AND THE QUALITY OF "PROGRESS"}

The explicit premise of the contractual price discrimination model is quantitative: Its adherents claim there will be more access and more creative output with contractual price discrimination than without it. The implicit premise is (necessarily) either that the shift in rules would be value-neutral as to quality-that is, that greater control would produce more of the same sorts of progressor, alternatively, that because copyright law strives for valueneutrality, it does not matter whether the sorts of progress produced under old and new rules are the same or different. Here, I argue that even if it worked perfectly, the contractual price discrimination model would be incapable of producing the same kinds and variety of progress, and distributing the same variety of crea-

22.Cf. DANiEL W. Bromley, Economic INTERESTS AND Institutions: The CONCEPTUAL FOUNDATIONS OF PUBLIC POLICY 137-39, 175-83 (1989) ("Judgments about social efficiency require that analysis be conducted against tbe backdrop of some social welfare function and its implicit social utility function."); C. Edwin Baker, The Ideology of the Economic Analysis of Law, 5 PHIL. \& PUB. AFF. 3, 6-7, 28-31 (1975) (arguing that "human satisfaction" is a function of distributive as well as efficiency considerations); Pierre Schlag, The Problem of Transaction Costs, $62 \mathrm{~S}$. CAL. L. REV. 1661, 1685 (1989) (arguing that normative judgments drive tbe clioice to characterize particular costs as (wasteful) transaction costs ratler than as necessary production costs).

23.See Cohen, supra note 20 , at $480-514$. 
tive materials as widely, as the traditional copyright framework. I argue, further, that these changes would matter. The shift to a regime of contractual restrictions on access and use will have important, and undesirable, substantive consequences for copyright's progress project. ${ }^{24}$

With respect to the creative progress criterion, the important question is whether contractual price discrimination will favor certain types of improvements, or certain types of new creation, over others. As noted above, the contractual price discrimination model predicts that rational copyright owners will license improvements at prevailing market rates. This, of course, is the way that many improvements are produced now. Many other improvements, however, do not require licenses. Some of these improvements involve fair use of copyrighted expression; other improvements, and much new creation, involve use of ideas and other uncopyrightable inputs. The shift to a pure licensing model raises questions about the continuing viability of these sorts of activities.

The prediction that granting increased control to copyright owners will promote the efficient licensing of formerly uncontrolled creation proves difficult to justify on a per-transaction basis. Even if we assume that copyright owners are, on the whole, rational and want to license improvements that will increase the value of their works, they will face problems in identifying worthy improvers and improvements. ${ }^{25}$ It is difficult to predict which ideas will bear the most promising creative fruit. For the same reason, would-be improvers who lack capital may have a hard time raising funds to pay the going rate for their desired uses. In addition, bargaining between current and future creators may entail strategic behavior and other significant transaction costs. ${ }^{26}$

More important, licensing decisions designed to maximize individual or private welfare may not maximize society's. ${ }^{27}$ And

24.This Part summarizes the analysis set forth in Cohen, supra note 20; for commentary in a similar vein, see Lemley, supra note 4; Lydia Pallas Loren, Redefining the Market Failure Approach to Fair Use in an Era of Copyright Permission Systems, 5 J. INTELL. PROP. L. 1, 8-32 (1997); Neil Weinstock Netanel, Copyright and a Democratic Civil Society, 106 YALE L.J. 283, $308-36$ (1996).

25.See Cohen, supra note 20, at 497-98 \& n.129; cf. Lemley, supra note 4, at 1055-56 (noting that uncertainty as to the nature of a proposed improvement may preclude an accurate assessment of the gains from trade).

26.See Lemley, supra note 4, at 1048-65; Netanel, supra note 24, at 334.

27.See Cohen, supra note 20, at 497-502; cf. BROMLEY, supra note 22, at 175-83 (demonstrating that "productive" or monetary efficiency is only one of the considerations that factor into the determination of whether a particular rule or practice is socially efficient); PAPANDREOU, supra note 21, at 225 ("П]nstitutional change does not require efficiency gains to be initiated, it 
because judging the "value" of most cultural works is an inherently subjective exercise, it is not clear that we want any one individual or entity to control decisions about which uses of a work are valuable. It is worth noting that some of the most detailed arguments about the importance of coordination, or stewardship, of improvements have been made about computer software-technical subject matter that has never fit comfortably within the copyright scheme. ${ }^{28}$ Even for computer software, moreover, the rise of the open source movement suggests that formal, centralized control is not needed to ensure high performance and interoperability. ${ }^{29}$

The answer to these objections offered by advocates of contractual price discrimination is that the market will nonetheless correct for individual instances of irrationality, misjudgment, and shortsightedness. This assumption about the aggregate neutrality of markets is a crucial conceptual underpinning of conventional legal-economic arguments for market ordering of entitlements. ${ }^{30}$ In fact, the assumption is at odds with the ways that information markets actually work, and it is especially unlikely to hold under contractual price discrimination.

requires gains to the initiators of change, which may or may not coincide with an overall increase in wealth."); AMARTYA K. SEN, CHOICE, WELFARE AND MEASUREMENT 288-90 (1982).

28.See, e.g., Kenneth W. Dam, Some Economic Considerations in the Intellectual Property Protection of Software, 24 J. LEGAL STUD. 321, 352-54, $361-66$ (1995); Douglas Lichtman, Property Rights in Emerging Platform Technologies, 29 J. LEGAL STUD. 615, 620-29 (2000); Ramsey Hanna, Note, Misusing Antitrust: The Search for Functional Copyright Misuse Standards, 46 STAN. L. REV. 401, 432-35 (1994).

29. See Peter Wayner, Free for All: How LinUX and the Free Software Movement UNDERCUT THE HIGH-TECH TITANS (2000). In theory, under existing copyright law, would-be improvers are free to reuse the functional principles embodied in competitors' software. See Sega Enters. Ltd. v. Accolade, Inc., 977 F.2d 1510, 1520-28 (9th Cir. 1992) (holding that fair use doctrine excuses intermediate copying during the course of reverse engineering to discover otherwise inaccessible functional principles); see also 17 U.S.C. § 1201(f)(1) (2000) (authorizing exemption from prohibitions relating to circumvention of technological protection devices for reverse engineering to discover requisites for interoperability). In practice, bowever, the interplay between copyright and trade secret law raises barriers to entry to a sufficient degree that hicensing may be preferred.

30.More precisely, neoclassical law and economics and the branch of economic tbeory from which it derives holds that absent significant transaction cost barriers, markets will order entitlements in ways that maximize wealth, and that this is optimal. See, e.g., Harold Demsetz, Toward a Theory of Property Rights, 57 AM. ECON. REV. 347, 349 (1967); Frank H. Easterbrook, Intellectual Property Is Still Property, 13 HARV. J.L. \& PUB. POL'Y 108 (1990); Edmund W. Kitch, The Nature and Function of the Patent System, 20 J.L. \& ECON. 265 (1977); see generally NICHOLAS MERCURO \& STEVEN G. MEDEMA, ECONOMICS AND THE LAW: FROM POSNER TO POSTMODERNISM 13-18, 57-60 (1997) (summarizing the tenets of "Chicago Scbool" law and economics); Netanel, supra note 24, at 321-24 (describing neoclassically oriented theorists' commitment to "legal marginahsm"). As I shall discuss, both propositions are open to serious doubt. 
First, considerable evidence suggests that real markets in contractually encumbered information goods will not operate quite as smoothly as the contractual price discrimination model predicts. There are important questions about the balance of power between providers and consumers of information goods that the conventional economic wisdom does not fully address. An imbalance may result if a particular content provider has a dominant market share, or a unique and nonsubstitutable work. Although a copyright does not necessarily guarantee market power, many information goods lack perfectly fungible substitutes. ${ }^{31}$ Even absent a commanding market share, market power may inhere in standard-form terms that are widely adopted within an industry. ${ }^{32}$ Such terms are increasingly common in information markets, and despite considerable evidence that information consumers want greater freedom, the major copyright owners do not seem to be competing among themselves to offer less restrictive terms. ${ }^{33}$

The contractual price discrimination model destabilizes the argument from markets still further. The ability to price discriminate requires at least one of the kinds of market power discussed above. ${ }^{34}$ In particular, contractual price discrimination presumes at

31.See Cohen, supra note 20, at 520-22 (discussing substitutability of information goods); $c f$. Meurer, supra note 6, at 870 (speculating that copyright may confer sufficient market power te enable price discrimination).

32.See Victer P. Goldberg, Institutional Change and the Quasi-Invisible Hand, 17 J.L. \& ECON. 461, 474-79, 484-88 (1974) (arguing that rulemaking via standard form provisions gives the upper hand to those entities that organize most efficiently in markets-namely, private firms).

33.See Cohen, supra note 20, at 521-30 (discussing examples). The controversy over digital music vividly illustrates this dynamic. Despite enormous consumer demand for a degree of un. restricted personal copying, the recording mdustry adamantly refuses to develop or license business models that would meet this demand. Instead, the Recording Industry Association of America is pursuing both an aggressive hitigation strategy and the Secure Digital Music Initiative, which it hopes will supply perfect metering capability for digital music files. See UMG Recordings, Inc. v. MP3.com, Inc., 92 F. Supp. 2d 349, 353 (S.D.N.Y. 2000) (granting summary judgment for plaintiffs on fair use defense asserted by supplier of technology designed to allow owners of sound recordings the ability te access them via the Internet from any computer); A\&M Records, Inc. v. Napster, Inc., No. C 99-5183, 2000 WL 1009483, at *7 (N.D. Cal. July 26, 2000) (enjoining technology designed to allow network users te locate and share files directly without need for a centralized index or file server), stay granted, No. 00-16401, 00-16403, $2000 \mathrm{WL}$ 1055915 (9th Cir. July 28, 2000); Ryan S. Henriquez, Facing the Music on the Internet: Identifying Divergent Strategies for Different Segments of the Music Industry in Approaching Digital Distribution, 7 UCLA ENT. L. REV. 57, 86-98 (1999). The Uniform Computer and Information Transactions Act, recently approved by the National Council of Commissioners on Uniform Stato Laws and already adopted in several states, would make it even easier for software manufacturers and database proprietors to impose similar restrictions. See Com Kaner, Why You Should Oppose UCITA, COMPUTER LAW., May 2000, at 20, 21-22.

34.See Meurer, supra note 6, at 870; see also Cohen, supra note 20, at 529-30 (discussing the market power that arises from imdustry standard-form restrictions and corresponding techno- 
least sufficient power to impose standard restrictions on redistribution and reuse. Market power, in turn, decreases the likelihood that irrational, misguided, or rationally self-centered but socially inefficient licensing decisions will be subject to market correction. In this respect, the contractual price discrimination model rests on a logical impossibility. As a result, it is unlikely to foster the sort of competition that its adherents claim is necessary for it to work.

There is a more fundamental objection to the contractual price discrimination model's progress claims, however. Basic economic theory suggests that rules that allow owners to appropriate more of the benefits that their works generate, and require improvers to internalize more of their costs, will systematically disfavor certain types of creation and.improvement. In particular, centralization of access control through more complete entitlements will result in the underproduction of information goods that generate significant public benefit. ${ }^{35}$ Creators of these works cannot appropriate all of the value that they create, and so will tend to undervalue their uses of preexisting works. ${ }^{36}$ For many of these creators, the profit motive is secondary; even so, these individuals face considerable monetary disincentives. ${ }^{37}$ Currently, limitations on copyright and institutions (such as libraries) that provide subsidized access to creative and informational works mitigate this problem. It is reasonable to predict that under contractual price

logical restrictions); Julie E. Cohen, Copyright and the Jurisprudence of Self-Help, 13 BERKELEY TECH. L.J. 1089, 1126-27 (1998) (same). In a recent paper, Michael Levine argues that price discrimination "very often occur[s] in competitive markets as a way of recovering costs common to producing more than one unit of a good or service. In these instances, price discrimination is simply a way of distributing the burden of common costs among customers in the way which permits the most efficient output from any given set of inputs." Michael E. Levine, Price Discrimination Without Market Power, Harvard John M. Olin Discussion Paper No. 276, at 4 (Feb. 2000). However, Levine is concerned solely with antitrust-style market power, and does not address industry power to set the standard terms that make price discrimination stick. See supra note 32.

35.See Cohen, supra note 20, at 542-51, Lemley, supra note 4, at 1056-58; Leren, supra note 24, at 49-56.

36.See Cohen, supra note 20, at 547; Lemley, supra note 4, at 1056; Loren, supra note 24, at 51-53.

37.See, e.g., Princeten Univ. Press v. Michigan Document Servs., 99 F.3d 1381, 1410 (6th Cir. 1996) (en banc) (Ryan, J., dissenting) (summarizing testimony of numerous academic authors "that they write for professional and personal reasons" and "that the receipt of immediate monetary compensation such as a share of licensing fees is not their primary incentive"); $c f$. John Kay, The Economics of Intellectual Property Rights, 13 INT'L. REV. L. \& ECON. 337, 345-46 (1993) (suggesting that in many cases the monetary value of a copyrighted work will bear no relation either to the "moral worth" of the work or to the incentives that led the author to create it). 
discrimination, the increased cost of inputs will deter at least some of these creators from proceeding. ${ }^{38}$

A contractual price discrimination regime also will not produce as great a variety of works as a system of less perfect control. C. Edwin Baker's study of the newspaper business demonstrates that an advertising-driven business model leads inexorably to monopoly provision of homogenized content, as information providers seek simultaneously to please their advertisers and appeal to the broadest possible customer base. ${ }^{39}$ Even in non-advertising-driven media markets, standardization of content may follow from the adoption of a particular business model. As Yochai Benkler shows, an information provider that amasses and reuses proprietary content can reduce its costs, and thus, over time, crowd out competitors who must create wholly new content and/or license their inputs from others. 40

These changes in the nature of progress also should inform consideration of how well a contractual price discrimination regime would serve copyright's distributional goals. As noted above, under a contractual price discrimination regime, information goods will be available more widely and at lower prices. In all likelihood, however, the quality of what is available will be different. Works offered at low prices for restricted use will be far more standardized, and will contain a lower proportion of the sort of "shared public benefit" content described above.

Speaking normatively now, these are changes that matter. Shared information goods are profoundly constitutive of social identity. It is one thing to say that the standard for copyright protection should not be elitist; it is quite another to say that

38. See Cohen, supra note 20, at 547 (noting, further, that "users may be disinclined (or simply unable) to pass increased license fees through te tbeir customer base because of limitations imposed by other institutional and social values").

39.See C. EdWin Baker, AdVertising and a Democratic Press (1994); see also Ben $\mathrm{H}$. BAGDIKIAN, THE MEDIA MONOPOLY (5th ed. 1997) (documenting increasing consolidation of tbe major copyright industries); BENJAMIN R. BARBER, JIHAD vS. MCWORLD 137-48 (1995) (same); EDWARD HERMAN \& NOAM CHOMSKY, MANUFACTURING CONSENT: THE POLITICAL ECONOMY OF THE MASS MEDIA 3-14 (1988) (same); Netanel, supra note 24, at 333 (observing that sectors of the media with significant concentration favor expression likely to appeal to large audiences).

40.See Yochai Benkler, Free as the Air to Common Use: First Amendment Constraints on Enclosure of the Public Domain, 74 N.Y.U. L. REV. 354, 402, 406-08 (1999) [hereinafter Benkler, Free as the Air]; Yochai Benkler, Intellectual Property and the Organization of Information Production 24, 29-33 (July 1999) (working paper) [hereinafter Benkler, Organization of Information Production], available at $\mathrm{http} / / \mathrm{www} . l \mathrm{aw} . n y u . e d u / b e n k l e r y / / p e c / p d f$. Michael Madison argues that tbe move to digital distrihution systems also will eliminate tbe diversity of textures and experiences that the less restrictive architecture of copyright law has fostored. See Michael J. Madison, Complexity and Copyright in Contradiction, 18 CARDOZO ARTS \& ENT. L.J. 125, 140-44 (2000). 
copyright entitlements must be reshaped in ways that systematically undervalue scholarship and avant-garde artistic and cultural expression. ${ }^{41}$ Similarly, while it is both right and fair to argue that copyright should seek to promote the widest possible dissemination of knowledge, it defies common sense to insist that this aspiration can be satisfied by substituting a diet of standardized, mass-produced "infotainment" for the broader diversity of content that fair use and freely accessible public libraries guarantee. ${ }^{42}$ Success in the mass market is not, and never has been, the only way our culture measures value. These are not the sorts of changes, and this is not the sort of "progress," that copyright law should seek to promote.

The problem confronting copyright law in the digital era may now be restated using a very different formulation than that offered by advocates of contractual price discrimination: Given increasing market pressures for greater control over access to and use of copyrighted works, how can we preserve or replace the important social benefits generated by areas 2 and 3 under the demand curve in Figure A-in other words, the benefits generated by a system of incomplete controls? ${ }^{43}$ Part IV considers this question and explores the role that economic modeling might play in answering it.

\section{MODELING UNPREDICTABILITY}

If the entitlement structures of copyright are not valueneutral, and if limitations on copyright scope play an important role in producing the kinds of progress we want, that does not quite end

41.We tend to forget that in Bleistein $v$. Donaldson Lithographing Co., Justice Holmes cautioned against both sorts of errors:

It would be a dangerous undertaking for persons trained only to the law to constitute themselves final judges of the worth of pictorial illustrations . . . At the one extreme some works of genius would be sure to miss appreciation. Their very novelty would make them repulsive until the public had learned the new language in which their author spoke. It may be more than doubted, for instance, whether the etchings of Goya or the paintings of Manet would have been sure of protection when seen for the first time. At the other end, copyright would be denied to pictures which appealed to a public less educated than the judge.

Bleistoin v. Donaldson Lithographing Co., 188 U.S. 239, 251.52 (1902).

42.See BARBER, supra note 39 , at 59-87 (coining the term to describe this sort of content).

43. Alternatively, government could subsidize the creation of works designed to benefit the public, and in some cases it does. But exclusive reliance on government subsidies to generate socially valued content is not the sort of solution that comports with our constitutional tradition of protecting information production from government oversight. See generally Netanel, supra note 24, at 352-59 (arguing that copyright serves the structural function of maintaining this separation). 
the matter. Practically speaking, efforts at contractual price discrimination are here to stay, driven both by profit incentives and by the relative ease of implementation via digital distribution technologies. Important questions remain about how copyright law should respond to these efforts. Can the contractual price discrimination model be adapted to ensure socially beneficial uses, as at least one of its advocates argues? Or does the key to copyright's future lie, instead, in its past? The answers to these questions highlight a fundamental tension inherent in efforts to construct economic models of the creative process, and suggest new directions for economic research into the conditions likely to foster ongoing, selfsustaining creativity within society.

William Fisher argues that the contractual price discrimination model can be adapted to preserve the important public benefits that the traditional copyright framework generates. Under Fisher's proposal, we would accept the stronger entitlements demanded by the contractual price discrimination model, but would impose a series of "compulsory terms" designed to preserve the public benefits of specified types of access and/or use. ${ }^{44}$ In this way, he argues, the price discrimination model can provide for important public policy exceptions while at the same time furthering both distributive justice and incentive-related goals.

Fisher's proposal is a serious effort to preserve the public benefits generated by the traditional framework, and deserves serious consideration. In particular, if that is the solution that best accommodates emerging market practices, then those who favor a system more closely resembling traditional copyright law need to explain why a regime of complete entitlements plus compulsory limitations is not functionally equivalent to a regime of incomplete entitlements. Clearly, one cannot distinguish the two by noting simply that the boundary between entitlement and exceptions will require judicial interpretation; this would be the case under either regime. There are, however, two weightier differences.

The first objection to Fisher's proposal is a practical one: The proposal takes insufficient account of the effects on individuals' abilities to make privileged uses of protected works. This is particularly true in cases where the more complete entitlements of the contractual price discrimination model are enforced by technical protection systems. ${ }^{45}$ Self-enforcing restrictions to which exceptions

44.Fisher, supra note 5, at 1241-51; see also Merges, End of Friction, supra note 11, at 134-35 (suggesting a similar approach).

45. See Cohen, supra note 34 , at 1140-42. 
exist only in theory, or as defenses to a breach of contract suit, will constrain individual behavior to a much greater degree.

The second defect in Fisher's proposal is conceptual, and lies in the presumption that access and use restrictions can be treated independently of one another. Fisher argues that his proposal will allow the law to recognize a more expansive set of privileges for "transformative" uses than the current fair use doctrine accommodates. We can afford to do so without sacrificing creation incentives, he says, if we balance these exceptions with stricter restrictions on transfer and reuse of copyrighted content. ${ }^{46}$ But what if one cannot so neatly separate the two?

At the very least, the suggestion that transformative use privileges can be divorced from copyright limitations that allow casual, unmonitored access to and sharing of information rests on some surprising and rather elitist presumptions. To say that access and reuse privileges may be granted separately presumes an ability to predict who will create. And, because as a practical matter reuse restrictions will burden lower-income users most heavily, it presumes that future creators are less likely to come from this class. ${ }^{47}$ Finally, it presumes that those who will not create immediately will not create at all, and will not use the information they have acquired to produce any other social benefit.

It is at least as likely that access and transformative reuse are two sides of the same coin-that creativity cannot be predicted ex ante; that the nature of the creative process requires adventitious access and reuse; that the rich are not always more creative than the poor; and that the temporal and causal connections between access and reuse are not always so close. ${ }^{48}$ If so, then even Fisher's modified contractual price discrimination model is flawed both descriptively and prescriptively. The imperfect correspondence

46. See Fisher, supra note 5, at 1251.

47. Fislier's suggestion that we might consider establishing a compulsory privilege for public library users comes closest to recognizing this problem. See id. (framing the question of library access as a distributive justice issue).

48. For a suggestive anecdote, see Dennis Cass, Let's Go: Silicon Valley!, HARPER's, July 2000, at 59, 66 (describing an interview with David Hecht, a scientist at the Xerox Palo Alto Research Center):

When I comment on his art books he lets a smile creep across his face and starts talking in a disjointed way about how he saw Sunday in the Park with George in 1984, which got him thinking about Seurat, which triggered a revelation about how to create pictures with backward and forward slashes he calls glyphs. I ask him if there is a correlation between art and technology. "Creative people are good at creating surprises," he says, slurring his speech out of shyness. "And it doesn't matter if you're creating with a brush or with equations." 
between pricing and value to consumers is a vital structural underpinning of the copyright system.

For the purposes of this Essay, though, whether I am right is beside the point. It is enough that there is doubt. If we cannot say with certainty which characterization of the creative process is the right one, we do not know enough about how the creative process works to attempt to formulate economic prescriptions for improving it.

The point underscores a deeper pitfall in the use of economic modeling to solve intellectual property problems. The premise of economic analysis is that it is possible to model assumptions and predict outcomes. Responsible economists acknowledge that some features of markets cannot readily be modeled or predicted. That is not necessarily a reason to forego modeling, particularly if the complex aspects are peripheral. Where complexity is central, however, and models overly reductionist, economic modeling may do more harm than good. It may cause harm, in particular, if it causes us to focus on and emphasize those aspects of the process that are least important-to overlook what is most vital in favor of what is easier to describe or model.

The particular brand of economic analysis practiced within the legal academy compounds this error. Conventional law and economics has overwhelmingly focused on generating static pictures of the demand and distribution curves for isolated goods at a particular point in time. As applied to information goods, this approach is especially perverse. Like a medieval mapmaker skirting the boundaries of terra incognita, it concentrates on the familiar and visible-transactions! licensing revenues!-and evinces little curiosity about the rest and its relation to the dynamic, irreducible whole. In place of the proverbial dragons, it assumes a benign universe-the hypothetical self-ordering market-as background, and thus avoids the difficulty of modeling the other complex systems that surround information production and use.

Second-generation research in the law and economics of intellectual property rights has begun to move beyond this approach. Scholars like Marshall Van Alstyne are attempting to model the ways in which exposure to information shapes demand for additional information. ${ }^{49}$ Other work has focused on understanding the ways in which the design of legal and market institutions, and the resulting constraints on access to and use of information resources,

49.See Marshall Van Alstyne, A Proposal for Valuing Information and Instrumental Goods (working paper 2000) (on file with author). 
affect further production. ${ }^{50}$ As discussed above, closer attention to the dynamics of information markets has shown that market-based ordering can result in inflexible standardization that rivals anything the public sector can produce. This work suggests that the institutional parameters of our information markets may need to be rethought. The question is not whether "public" or "private" ordering is better, but rather what combination of public and private ordering will produce the socially optimal result. Finally, scholarship in copyright and allied fields is beginning to marry the insights of economics with those of post-modern and critical information theory, which focus on how information constructs methodology and ideology, and with work in cognitive theory and philosophy of science that explores the ways in which information systems and technologies shape perceptions of reality. ${ }^{51}$ These preliminary efforts to map the dynamics of information exchange and their relation to institutional variables provide a foundation upon which to build.

The problems that economic modeling of intellectual property rights must solve, in short, are very different from the ones posited by advocates of contractual price discrimination. What is missing from the conventional economic wisdom about property rights in general and intellectual property rights in particular is a vocabulary for apprehending the link between incomplete control and productivity, between "leaky" entitlements and public welfare, between chaos and creative ferment. ${ }^{22}$ The fact that we cannot iden-

\footnotetext{
50.See Benkler, Free as the Air, supra note 40; Benkler, Organization of Information Production, supra note 40; Cohen, supra note 20; Niva Elkin-Koren, Turning Culture into a Market for Consumer Goods (working paper 2000) (on file with author).

51. See JAMES BOYLE, SHAMANS, SOFTWARE, AND SPLEENS: LAW AND THE CONSTRUCTION OF THE INFORMATION SOCIETY 35-60 (1996); Dan L. Burk, Patenting Speech, 79 TEX. L. REV. (forthcoming 2000); Julie E. Cohen, A Right to Read Anonymously: A Closer Look at "Copyright Management" in Cyberspace, 28 CoNN. L. REv. 981, 1004-07 (1996); Niva Elkin-Koren, Copyright Law and Social Dialogue on the Information Superhighway: The Case Against Copyright Liability of Bulletin Board Operators, 13 CARDOZO ARTS \& ENT. L.J. 346, 391-401 (1995); Netanel, supra note 24, at 332-33; cf. J. M. BALKIN, CULTURAL SOFTWARE: A THEORY OF IDEOLOGY 23-97 (1998) (exploring tbe gradual evolution of ideas and behefs within society); James Boyle, Foucault in Cyberspace: Surveillance, Sovereignty, and Hardwired Censors, 66 U. CIN. L. REv. 177, 184-88 (1997) (discussing the potential for digital information technologies to control and monitor information use); Julie E. Cohen, Examined Lives: Informational Privacy and the Subject as Object, 52 STAN. L. REV. 1373, 1396-98, 1404-08 (2000) (discussing tbe use of personal identifying information to shape desire, opportunity, and potentially behavior).

52.In contrast, the common law of property acbieves an intuitive, equitable recognition of the role that limited entitlements can play in maximizing society's welfare. As Carol Rose demonstrates, the common law histerically recognized a species of "limited common property" in roads and waterways that enabled access to, and thus more efficient exploitation of, the surrounding private property. See generally Carol Rose, The Comedy of the Commons: Custom, Commerce,
} 
tify improvers or predict improvements in advance is not a weakness to be minimized or ignored, but a strength to be celebrated. We need an economic syntax that acknowledges and accommodates the essentially unpredictable nature of creativity, and an economic model that focuses on creating the conditions for random or fortuitous access to copyrighted content-in other words, on preserving "open spaces" under the copyright demand curve. Promising work on these problems has begun to supply the foundation; what is needed is to acknowledge the goal and the methodological challenges it poses.

\section{CONCLUSION}

Copyright's progress mandate demands that we develop a system of rights and rules to foster creativity. It does not tell us how. Particularly in its more sophisticated incarnations, the contractual price discrimination model is a serious, good-faith effort to optimize copyright for the digital age. But the model stumbles, fatally, in its failure to understand the phenomenon upon which it seeks to improve.

Before we can construct a reliable system of entitlements and public policy exceptions to promote the twin goals of progress and access, we must learn to understand and describe creative processes more accurately. We need to understand how people get ideas, and how ideas migrate and transform within society. And we must learn how to design open spaces-zones of unpredictability within and around the predictable contours of rights and rules. Only then can we proceed to construct a regime that will optimize for those aspects of the creative process that are most valuable. In the end, we may well find that that regime bears a closer resemblance to the copyright regime we already have.

and Inherently Public Property, 53 U. CHI. L. REV. 711 (1986). Access that is only partially regulated by law, and partially regulated, as well, by community norms of fair play and acceptable behavior, is an integral part of a well-functioning, usable system of property rights. The analysis here suggests that similar principles apply to property rights in intangibles, although the geography of exploitation is different. 
HeinOnline -- 53 Vand. L. Rev. 18202000 